\title{
Study of older adolescents diet and their preferences among functional nutrition products
}

\author{
M.S. Gorbunchikova ${ }^{1, *}$, and L.M. Zakharova ${ }^{1}$ \\ ${ }^{1}$ Federal State Budgetary Educational Institution of Higher Education "Kuzbass State Agricultural \\ Academy", 650056 Kemerovo, Russian Federation
}

\begin{abstract}
The article presents the results of a survey of older adolescents among students. The structure of nutrition of adolescents is analyzed. It was found that the majority of students' nutrition is not balanced, carbohydrate-containing foods predominate. There is a lack of protein, dietary fiber, vitamins and minerals. The diet of students is not observed. It is noted that at this age, many respondents have chronic diseases. It was found that most adolescents have an idea of functional nutrition products, but the frequency of consumption of such products among this category of the population often depends on the cost. As fortified foods, adolescents would prefer soft drinks, confectionery and bakery products, dairy products and fortified "fast food". Measures to improve the health of adolescents are proposed.
\end{abstract}

\section{Introduction}

Nutrition is one of the many factors that ensure normal growth, development of the body, its performance, and resistance to various diseases [1]. How much food is absorbed by the body depends not only on the composition and amount of food consumed, but also on its physiological characteristics. Perception and sensitivity to food varies from person to person. Therefore, an individual approach to nutrition is necessary [2, 3].

Adolescence is a stage in a person's life characterized by physiological and psychological changes that result in the formation of personality and adulthood occurs. According to various sources, this period starts from 12 and lasts up to 18-19 years. Psychologists distinguish between younger adolescence (from 12 to 14 years) and older adolescence (from 15 to 18-19 years). Adolescents are one of the most vulnerable groups of the population, due to physiological changes in the body, as well as the impact on them of a huge number of negative factors, such as violation of the work and rest regime, frequent stress and information overload, often the need to combine study and work, violation of the regime and diet. All this leads to the development of diseases of the gastrointestinal tract, cardiovascular, nervous and other systems of the body. [4].

Violation of the structure of nutrition, according to academician V.A. Tutelyan, causes irreparable damage to human health [5].

\footnotetext{
${ }^{*}$ Corresponding author: marina.gorbunchikova@rambler.ru
} 
Previous studies have shown that diabetes mellitus, duodenal and gastric ulcers, coronary heart disease, increased risk of various neoplasms, and a number of other diseases are closely associated with an unbalanced diet $[3,6,7]$.

Functional foods can help to balance the diet, as they have a high degree of usefulness, and are also safe compared to medications. Therefore, they can be used to prevent the development of alimentary diseases [8-10].

In connection with all the above, it was decided to study the actual diet and nutrition structure of older adolescents, as well as their awareness of functional products and preferences in these products.

\section{Materials and methods}

A pilot study was conducted in the form of a questionnaire among students of secondary vocational and higher education institutions in the city of Kemerovo.

The questionnaire consisted of two types of questions: the questions of the first group assumed the choice of the answer from the offered options, the rest of the questions - an independent answer.

\section{Results and discussion}

The survey involved 230 people (140 girls and 90 boys).

The structure of modern human nutrition is closely related to the level of income. According to the survey, depending on the level of income per family member, the following groups are identified: with an income of up to 6000 rubles $-6 \%$, up to 10,000 rubles $-10 \%$, up to 14,000 rubles $-48 \%$, up to 16,000 rubles $-30 \%$, over 16001 rubles -6 $\%$.

In its turn, the level of income depends on the composition of the family. It was revealed that $9 \%$ of people participating in the survey were from large families; $9 \%$ of adolescents - in families consisting of two people; $37 \%$ - from four and the largest number of respondents ( $45 \%$ ) said that their family consists of three people. It should be noted that among all respondents, $31 \%$ are brought up in single-parent families, as a rule, their income level is no more than 16,000 rubles.

It is known that a healthy lifestyle is based on three main components: healthy diet, physical activity and rejection of bad habits. In this regard, a survey was conducted on physical activity, the presence of bad habits and existing diseases. When asked about physical activity, the majority of students (64\% in total) said that they work out in the gym, fitness, yoga, dance, or "keep fit yourself by running in the morning", less often - indicated a specific sport $-2 \%$, the rest of the respondents are not physically active. $20 \%$ of respondents have bad habits. According to the data obtained, $27 \%$ of respondents already have any chronic diseases (gastritis, cholecystitis, bronchitis, etc.).

At the first stage, it was necessary to find out the nutritional characteristics of the respondents. According to the survey, the majority of students eat 1-2 times a day (69\%), and this is most often explained by the fact that they "do not have time to have breakfast", $23 \%$ - eat regularly 3-4 times a day, and $8 \%$ of teenagers have a frequency of meals -5 or more times a day (mainly due to the prescribed diet for health reasons).

Based on the survey conducted (table 1), it was found that the nutrition of adolescents is not rational, since most of them prefer bread, bakery and confectionery products. More than $50 \%$ of students wrote that they mostly eat potatoes from vegetables. If we consider questionnaires by gender, it should be noted that girls are more likely to consume milk and dairy products, while young men prefer to have meat and meat products in their diet. It is 
extremely rare for adolescents to eat fish. The frequency of fruit consumption is also low for most respondents. Often, cereals and pasta appear in the diet of adolescents. During the sessions, many students are more likely to consume "fast food", confectionery (in particular chocolate) and coffee.

Table 1. Frequency of food consumption among older adolescents

\begin{tabular}{|c|c|c|c|c|c|c|c|}
\hline \multirow{2}{*}{$\begin{array}{l}\mathrm{N} \\
\mathrm{o}\end{array}$} & \multirow{2}{*}{$\begin{array}{l}\text { Consumed } \\
\text { products }\end{array}$} & \multicolumn{6}{|c|}{ Consumption frequency, $\%$} \\
\hline & & $\begin{array}{l}\text { once } \\
\text { a day }\end{array}$ & $\begin{array}{l}\text { several } \\
\text { times a } \\
\text { day }\end{array}$ & $\begin{array}{l}\text { several } \\
\text { times a } \\
\text { week }\end{array}$ & $\begin{array}{l}\text { several } \\
\text { times a } \\
\text { month }\end{array}$ & $\begin{array}{l}1-2 \text { times in } \\
\text { several } \\
\text { months }\end{array}$ & $\begin{array}{l}\text { not } \\
\text { consume } \\
\text { d }\end{array}$ \\
\hline 1 & $\begin{array}{l}\text { Bread and bakery } \\
\text { products }\end{array}$ & 11 & 88 & 1 & - & - & - \\
\hline 2 & Cereal products & - & - & 98 & 2 & - & - \\
\hline 3 & Pasta & - & - & 80 & 20 & - & - \\
\hline 4 & Vegetables & 12 & 9 & 52 & 26 & 1 & - \\
\hline 5 & Fruits & 5 & 0.5 & 16 & 66 & 12.5 & - \\
\hline 6 & Mushrooms & - & - & - & 23 & 44 & 33 \\
\hline 7 & Tea, coffee & 1 & 99 & - & - & - & - \\
\hline 8 & Soft drinks & 17 & 19 & 39 & 24 & 1 & - \\
\hline 9 & Confectionery & 27 & 25 & 28 & 15 & 3 & 2 \\
\hline 10 & $\begin{array}{l}\text { Milk and dairy } \\
\text { products }\end{array}$ & 38 & 10.00 & 39 & 12.5 & - & 0.5 \\
\hline 11 & $\begin{array}{l}\text { Meat and meat } \\
\text { products }\end{array}$ & 18 & 1 & 29 & 50 & 1 & 1 \\
\hline 12 & Eggs & 1 & - & 21 & 77 & - & 1 \\
\hline 13 & Fish and seafood & - & - & 1 & 38 & 58 & 3 \\
\hline 14 & "Fast food" & 28 & 11 & 42 & 14 & 3 & 2 \\
\hline
\end{tabular}

The second stage of the study included the study of adolescents' awareness of functional nutrition products. The majority of respondents $(48 \%)$ wrote that "a functional product is a product enriched with something", another $10 \%$ expressed the opinion that it is a dietary supplement, and $7 \%$ suggested that "it is a product that has some function", the rest found it difficult to answer this question.

When asked to give an example of a functional nutrition product, respondents most often listed: bio-yoghurts, muesli, sports cocktails, dietary supplements.

Further, the frequency of consumption of functional nutrition products by adolescents was investigated. $40 \%$ of the respondents say that they do not use such products, $35 \%$ buy bio-yoghurts, fortified bars, muesli, the rest of the respondents answered that they do not pay attention to whether it is a functional product or not.

It was interesting to find out what attitude teenagers have to functional products. The data obtained in the course of the study show that $25 \%$ of respondents have a positive attitude and often buy them because they care about their health. Some students $(40 \%)$ associate such products with something useful, but tasteless, and also quite expensive, so they are either not ready to buy them at all, or they can buy them if there is a discount. The rest of the study group found it difficult to answer this question.

The task of the study was also to study the opinions of adolescents about what functional foods should be fortified and why. Functional soft drinks (26\%) and confectionery $(24 \%)$ will be the most popular among adolescents, since they are delicious and convenient to take with you as a "snack". Also, $8 \%$ would buy fortified bakery 
products and $9 \%$ of people would prefer fermented milk products (in both cases, explaining the frequency of their consumption). $3 \%$ of students said they would like to buy healthy chips, crackers and salted nuts. Some respondents $(1 \%)$ wrote that they do not want to buy functional products at all, because they consider it "impractical to buy expensive products". The rest of the respondents found it difficult to answer.

\section{Conclusions}

Thus, as a result of the conducted research, it was revealed that the diet of older adolescents is unbalanced. The carbohydrate component prevails, due to the frequency of consumption of bread and bakery products, pasta, confectionery, and potatoes. There is a lack of dietary fiber, vitamins and minerals - due to infrequent consumption of fruits and vegetables. There is an imbalance in protein, due to a lack of dairy, meat products, eggs and fish in the diet.

It was found that the multiplicity of students' meals also does not correspond to the norm.

The majority of respondents have an idea of what functional nutrition products are, but only $35 \%$ of respondents use them. According to teenagers, preference will be given to fortified confectionery and bakery products, soft drinks, dairy products and fortified "fast food".

It should be noted that adolescence is one of the most crucial periods in a person's life. At this time, the formation of physical health and cultural skills that ensure its improvement, strengthening and preservation in the future takes place. That is why education should form the optimal level of health of a teenager. Currently, it is necessary to consider the educational process of students in parallel with the health-improving one. According to article 41 of the Federal law dated 29.12.2012 No. 273-FZ (ed. dated 31.07.2020) "On education in the Russian Federation", organizations that carry out the educational process must not only comply with state sanitary and epidemiological rules and regulations, but also carry out preventive and health-improving measures, as well as training and education in the field of health protection.

The health problem cannot be solved only by the healthcare authorities. Adolescents should be taught with health, the rules of personal behavior should be brought up that meet the principles of a healthy lifestyle, including rational nutrition, rejection of bad habits, etc. In order to ensure the prevention of morbidity among adolescents, improve their health in the activities of educational institutions, we consider it necessary to introduce the optional discipline "Healthy food" in all areas of education. Development of recreational and educational programs for students teenagers should consider the following principles: medical-biological characteristics of the organism at the age from 14 to 18 years; the individual health of modern teenagers, the nature of their diseases; role of nutrition in the formation of the body (plastic, energy, etc.). When studying this discipline, it is necessary to interest students in a variety of healthy food products containing healthy ingredients; to develop an understanding of the need for their daily use in order to preserve and improve their health. The health and education program benefits everyone: students, parents, producers, and the nation as a whole.

\section{References}

1. V.M. Poznyakovsky, T.M. Drozdova, P.E. Vloshchinsky. Physiology of nutrition Saint-(Petersburg: Publishing House "Lan", 2018)

2. L.A. Mayurnikova, S.D. Rudnev, N.I. Davydenko, S.V. Novoselov, D.G. Popova. Foods and Raw Materials, 6(1), 79-89 (2018) 
3. L.A. Mayurnikova, S.F. Zinchukc, N.I. Davydenkoa, S.A. Gilmulina, Foods and Raw Materials, 5(2), 178-188 (2017)

4. E.F. Zeer, Psychology of professional education: textbook for students of higher professional educational institutions, (Moscow: Publishing Center "Academy", 2013)

5. A.N. Razumov, A.I. Vyalkov [et al.]. Scientific foundations of healthy, (M.: Panorama, 2010)

6. On the state of the sanitary and epidemiological population of the Russian Federation in 2014, Federal Service for Supervision of Consumer Rights Protection and Human Welfare, (Moscow, 2015)

7. G.N. Zabegalova, L.A. Urenkova, T.Y. Burmagina, Journal of Hygienic Engineering and Design, 29, 77-80 (2019)

8. A.V. Zaushintsena, I.S. Milentyeva, O.O. Babich, S.Yu. Noskova, T.F. Kiseleva, D.G. Opova, I.A. Bakin, A.A. Lukin, Foods and Raw Materials, 7(1), 84-92 (2019) DOI: http://doi.org/10.21603/2308-4057-2019-1-84-92

9. N.I. Usenko, E.K. Khlestkina, S. Asavasanti, E.I. Gordeeva, R.S. Yudina, et al. Foods and Raw Materials, 6(1), 128-135 (2018) DOI: https://doi.org/10.21603/2308-40572018-1-128-135.

10. L.M. Zakharova, I.N. Pushmina, V.V. Pushmina, M.D. Kudriavtsev, S.S. Kudriavtsev, S.S. Sport, Medicine, 19(S1), 128 -136 (2019) (in Russ.) DOI: 10.14529/hsm19s117 